\title{
Genetic predisposition for productive life is associated with functional inactivation of a AP2-binding site in the promoter of the stress protein 70.1-encoding gene in cattle
}

\author{
Dedicated to Prof. Dr. agr. habil. Dr. h. c. mult. Georg Schönmuth on the occasion of \\ his $75^{\text {th }}$ birthday
}

\section{Summary}

The complex pattern of action for cell viability makes the heat shock protein (HSP) loci to potential candidate genes for stress susceptibility. In the bovine hsp70.1 gene a functional AP2 box variant affecting a significant decrease of cellular stress response, was described. To monitor the distribution of this promoter variant in phenotypically different populations a diagnostic PCR-RFLP assay was developed. As an indicator for individual stress susceptibility the phenotypic trait 'productive life' was measured based on the assumption that animals having longer 'productive life' might be superior in coping with stress during lifetime. Association of the observed promoter variant with the estimated breeding value 'productive life time' was studied in a Holstein sire population and a granddaughter design. Our observations suggest that this polymorphism affects productive life in cattle. Animals with a normal AP2 box are characterised by an increased stress tolerance concluded from their prolonged productive life. These results are supported by the observed different distribution of the $h s p 70.1$ promoter variant in cows of different lactation numbers and degree of selection. Frequency of the mutant hsp70.1-AP2 box allele is significantly lower in cows selected as dams of sires and in cows with an increased lactation number. Additionally, cows with a mutant hsp70.1-AP2 box variant exhibited an increased hazard for culling.

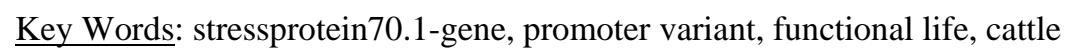

\section{Zusammenfassung}

Titel der Arbeit: Die genetische Prädisposition für Nutzungsdauer ist mit der funktionellen Inaktivierung eines AP2-Bindungsortes im Promotor des Stressprotein70.1-Genes beim Rind assoziiert

Das komplexe Wirkspektrum beim Überleben von Zellen macht die Hitzeschockproteingene zu potentiellen Kandidatengenen für die Stressempfindlichkeit. Im bovinen hsp70.1-Gen wurde eine funktionelle AP2-BoxVariante beschrieben, die eine signifikante Verminderung der zellulären Stressreaktion bewirkt. Mit dem Ziel die Häufigkeit dieser Promotorvariante in phänotypisch differenten Populationen zu untersuchen, wurde ein diagnostischer PCR-RFLP-Test entwickelt. Ausgehend von der Annahme, dass Tiere, die eine verlängerte Nutzungsdauer besitzen, in der Stressbewältigung während der Lebenszeit überlegen sein könnten, wurde das phänotypische Merkmal "Nutzungsdauer" als Indikator für die individuelle Stressempfindlichkeit bestimmt. Die Assoziation der beobachteten Promotorvariante mit dem Zuchtwert Nutzungsdauer wurde in einer Holstein Bullenpopulation und einem Enkelinnen-Design untersucht. Unsere Beobachtungen weisen darauf hin, dass dieser Polymorphismus die Nutzungsdauer beim Rind beeinflusst. Tiere mit einer normalen AP2-Box sind nach Maßgabe ihrer verlängerten Nutzungsdauer durch eine erhöhte Stresstoleranz charakterisiert. Diese Ergebnisse werden durch die beobachtete unterschiedliche Häufigkeit der hsp70.1-Promotorvarianten bei Kühen mit einer unterschiedlichen Laktationsnummer bzw. Grad der Selektion unterstützt. Die Häufigkeit des mutierten AP2-BoxAlleles ist bei Kühen, die als Bullenmütter selektiert wurden, und bei Kühen mit einer erhöhten Laktationszahl signifikant geringer. Darüber hinaus weisen Kühe mit einer mutierten AP2-Box-Variante ein erhöhtes Merzungsrisiko auf. 


\section{Introduction}

During the last 5 decades, genetic improvements have tremendously increased the economic efficiency of many domestic animals, mainly due to the consequent application of the principles and means of quantitative genetics and statistics. However, despite those dramatic improvements concerning some of the economically important traits in several species of domestic animals, several limitations of traditional breeding methods are becoming more and more apparent particularly concerning traits that are difficult to measure, appear late during ontogenesis, are genetically negatively correlated with other economically important traits or have a low heretability. Many of these conditions are valid for functional traits that are becoming more and more impact under consideration of public demands for animal welfare and health. Molecular analysis of the genomes of farm animals may help to solve some of these problems (GEORGES and ANDERSSON, 1995). In the past few years there was remarkable progress in detecting genomic regions containing QTL especially concerning milk performance, growth, exterior, genetic diseases, but also functional traits in cattle. However, for efficient marker-assisted selection the ultimate target is to get from fine mapped QTL to the gene itself, where candidate genes can be directly tested for their association to particular traits. Developed comparative map in combination with highdensity physical maps of human and mouse are a valuable tool for identification of positional candidate genes in livestock animals. Genome scans in cattle for QTL identified a genomic region affecting stillbirth, calving difficulties and longevity that is localized on the middle part of bovine chromosome 23 (BTA23) within the vicinity of the major histocompatibility complex (e. g. GRUPE et al., 1998).

The localisation of inducible $h s p 70$ genes at the MHC gene region in human (SARGENT et al., 1989), rat (WURST et al., 1989), goat (CAMERON et al., 1990), mouse (GASKINS et al., 1990), cattle (GROSZ et al., 1992) and swine (NUNES et al., 1993) and the complex pattern of action in thermotolerance, in the ability of the cell to survive injury and oxidative stress, and their potential contribution to the association of the $M H C$ gene region with disease in particular, makes the hsp70 loci to potential candidate genes in stress-protective function. Living organisms respond to stress at the cellular level by a transient but rapid and strong increase in the biosynthesis of various stress proteins including those of the heat shock protein (Hsp)70 family. The Hsp70 frequently constitute the predominant fraction of protein synthesis in stressed cells and play a central role in proper folding, oligomerisation, and transport of polypeptides across membranes (CRAIG and GROSS, 1991; HIGHTOWER, 1991). Expression of inducible $h s p 70$ genes is regulated mainly at the transcriptional level pointing out the possible impact of $h s p 70$ promoter variants on cellular stress response (TANGUAY, 1988; WU et al., 1985). In cattle breeds two polymorphisms were detected in the bovine hsp70.1 promoter sequence of which one altered the AP2 box at position -130 (SCHWERIN et al., 2001). This potential cis-acting element was shown to interact with the purified transcription factor AP2. The deletion of a $\mathrm{C}$ residue observed within the -130 AP2 box significantly reduced factor binding. Inactivation of the AP2 site in the bovine hsp70.2 promoter resulted in a significantly decrease of heat-induced transcription compared to the wild type-promoter. To conveniently monitor the distribution of these promoter variants in phenotypically different populations a diagnostic PCR-RFLP assay was developed. A suitable phenotypic trait of stress susceptibility in cattle is not available at present. Based on the assumption that animals 
having longer "productive life" might be superior in coping with stress, the association of the observed promoter variants with the estimated breeding value 'productive life time' was studied in a Holstein sire population and a granddaughter design.

\section{Materials and methods}

PCR-RFLP assay. The DNA was extracted from blood by standard methods (MANIATIS et al., 1982). The deletion of a $C$ residue observed within the -130 AP2 box creates a ScrFI restriction site. We developed a PCR-RFLP assay for this polymorphism. The PCR was performed in a total volume of $100 \mu$ l containing approximately $0.5 \mu$ g genomic DNA, $10 \mathrm{mM}$ Tris- $\mathrm{HCl}, 50 \mathrm{mM} \mathrm{KCl}, 1.5 \mathrm{mM} \mathrm{MgCl} 2$, $0.01 \%$ gelatine, $250 \mathrm{mM}$ of each $\mathrm{dNTP}$, and 5 units Taq-polymerase (Appligene, Heidelberg, Germany). Initial denaturation was for 5 min (at $94{ }^{\circ} \mathrm{C}$ ) followed by 40 cycles of $94{ }^{\circ} \mathrm{C}$ denaturation $(1 \mathrm{~min}), 63^{\circ} \mathrm{C}$ annealing (1 min) and $72{ }^{\circ} \mathrm{C}$ extension (2 min). The PCR product was sized by electrophoresis in $1 \%$ agarose MP (Boehringer Mannheim, Germany). The respective PCR primers were derived from the appropriate EMBL sequence file (GROSZ et al., 1992). We used a two-step protocol for PCR amplification, firstly generating a bovine $h s p 70.1$ gene specific DNA fragment using gene diagnostic primers (forward and reverse, respectively): 5'GTCGCCAGGAAACCAGAGAC and 5'-GGAACACCCCTACGCAGGAG (positions 181-200 and 712-731, respectively, GenBank accession number M98823). The generated PCR products were used in a second PCR for diagnostic amplification of the polymorphic site using modified primers (modified nucleotides are underlined) to eliminate three native ScrFI restriction sites remaining the diagnostic ScrFI restriction site only: 5'-GTTCTGGGAGGAGAGGCATTCAG and 5'CTGCCATGTCGGGAATATTCAAA-GG (positions 284-306 and 356-379, respectively, GenBank accession number M98823). Frequencies of these polymorphisms in the populations were analysed via restriction digestion of PCR fragments using ScrFI. The 96 bp comprising amplicon of the homozygous wild type allele is not digested by ScrFI whereas digestion of the mutated type allele is resulting in the diagnostic fragments of 49 and 47 bp (Figure 1).

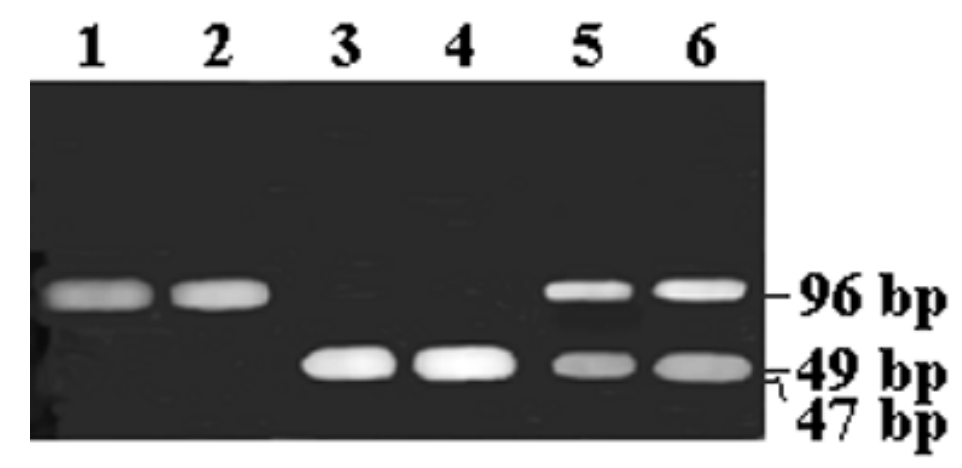

Fig. 1: Electrophoretic banding pattern of the different bovine hsp70.1-AP2 box genotypes (lane 1 and 2: homozygous normal; lane 3 and 4: heterozygous; lane 5 and 6: homozygous mutant AP2-box) after two-stepPCR and ScrFI digestion

Animals. Distribution of bhsp70.1 genotypes was analysed in 302 cows of different lactation numbers ( $\mathrm{n}_{\text {lactation } 1-6}=165, \mathrm{n}_{\text {lactation }>10}=137$ ) and 115 dams of sires of Holstein bred. Association of bhsp70.1 promoter variants was studied in a Holstein cow population of in total 292 sires and a granddaughter design comprising 9 sire 
families with in total 106 sons respectively. Additional, in 7 local herds of Mecklenburg-Western Pomerania hazard for culling of cows was studied among progeny groups of two bulls that are heterozygous for the AP2 variant within the first four lactations under consideration of the paternal alleles.

Statistical Analyses. Frequency tests were carried out using analysis of contingency tables by SAS (1999). The statistical model analysing the effects of $h s p 70.1$ genotypes on productive life time included fixed effects as follows:

$$
\begin{aligned}
& y_{i j k}=s_{i}+d_{i j}+g_{k}+e_{i j k} \\
& \text { with } \quad s \quad \text { - sire } \\
& \text { d } \quad \text { - dam (s) } \\
& \text { g - hsp70.1-AP2 box genotype (CC, C-, - -) } \\
& \text { e - residual }
\end{aligned}
$$

The estimations and tests were carried out using the GLM procedure of SAS (1999).

\section{Results}

Frequency of the mutant hsp70.1-AP2 box allele is significantly lower in cows selected as sire dams and in cows with an increased lactation number

Figure 2 shows frequencies of hsp70.1-AP2 box genotypes of randomly selected Holstein cows with different productive life (lactation no. 1-6 vs. lactation no. >10) among female progenies of the same bulls and of cows used as sire dams. The frequency of the defect AP2 allele is significantly decreased both in cows with increased lifetime (lactation no. 1-6: $p=0.33$; lactation no. $>10: p=0.10$ ) and in cows selected for production of sires (sire dams: $\mathrm{p}=0.18$ ). These results suggest that the promoter variant analysed is not selectively neutral. To study potential phenotypic effects of this $h s p 70.1$ promoter variant its association with the estimated breeding value productive life was investigated.

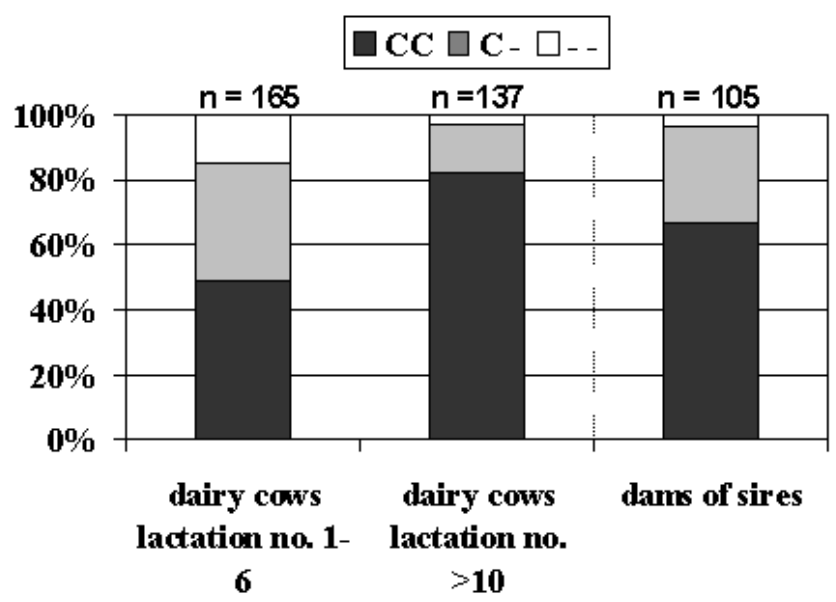

Fig. 2: Distribution of bovine hsp70.1-AP2 box genotypes in Holstein cows with different lactation numbers

Functionally inactivated hsp70.1-AP2 box variant is associated with a reduced productive life in cattle

Association of the bovine $h s p 70.1$ promoter variants was studied in a Holstein sire population and a granddaughter design respectively. Figure 3A shows the genotype 
effects on the relative EBV productive life of 292 sires. Homozygous mutant sires show a tendentious reduction $(P=0.150)$ of the relative EBV productive life. The same tendency was observed considering effect of paternal alleles on the relative EBV productive life in a granddaughter design comprising 9 sire families with in total 106 sons (Figure 3B). The unbalanced mean of relative EBV in sons inherited the paternal allele "C" was remarkably, but not statistically significant higher compared to the sons inherited the paternal allele “-“ (103.0 vs. 93.0). In family 1 only (Figure 3C), the relative EBVs productive life between both groups inherited the alternative paternal alleles were highly significantly different (allele "C”: 108.0 vs. allele “-“: $91.0 ; P<$ 0.003).

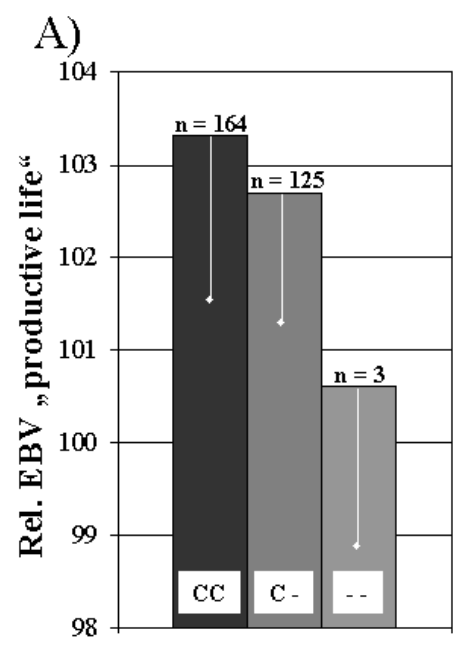

B)

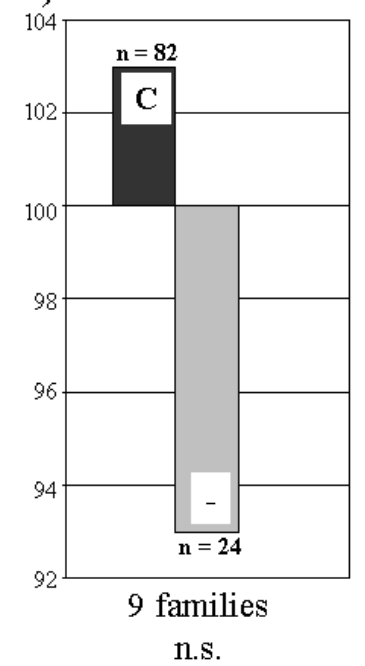

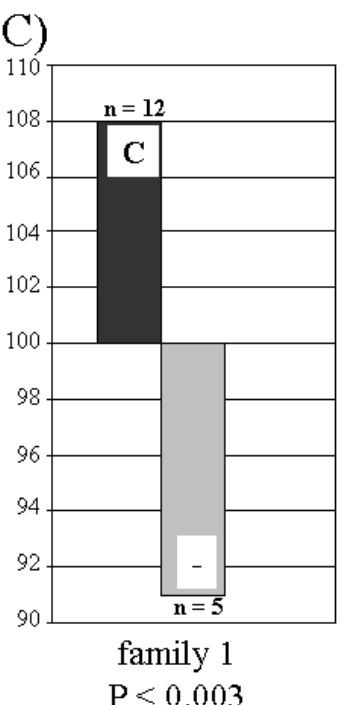

Fig. 3: Association of the bovine hsp70.1 promoter variant: A) Genotype effects on the relative estimated breeding value $(E B V)$ productive life in a Holstein sire population $(n=292)$. B) Effect of paternal hsp70.1 alleles on relative EBV productive life in a Holstein granddaughter design comprising 9 sire families with in total 106 sons. C) Effect of paternal hsp70.1-alleles on relative EBV productive life in family1 with 17 sons

Cows with a mutant hsp70.1-AP2 box variant exhibited an increased hazard for culling

Culling of cows was monitored among progeny groups of two sires that are heterozygous for the AP2 box variant over a period of four lactations. Figure 4 shows frequencies of daughters of both sires culled within the first three lactations or arrived the fourth lactation under consideration of the inherited paternal allele. In both progeny groups all of the progenies that inherited the mutant paternal allele (homozygous "- -“ animals) were culled before the end of the third lactation. In contrast, 42.1 and $23.5 \%$, respectively, of the daughters that inherited the wild type allele (homozygous "CC" animals) were alive in the fourth lactation. 


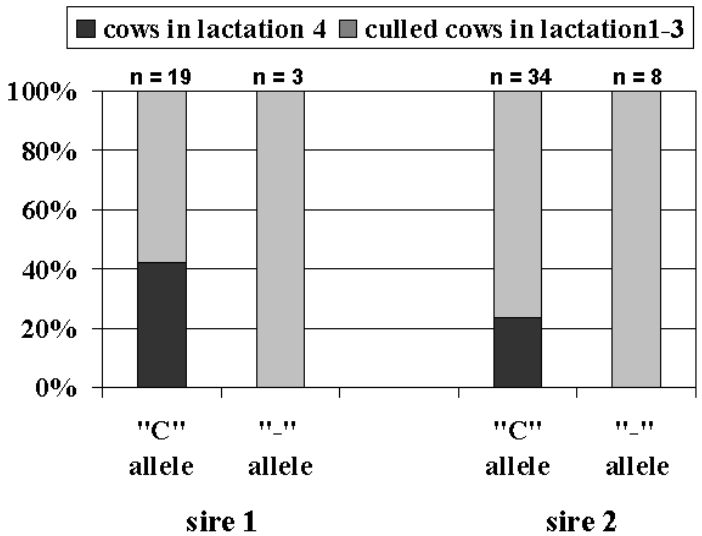

Fig. 4: Culling rate in female progeny groups of two Holstein sires that are heterozygous for the AP2 box variants of the bovine hsp70.1 gene in 7 local herds of Mecklenburg-Western Pommerania over a period of four lactations under consideration of the inherited paternal AP2 allele

In Holsteins carriers of the bovine hsp70.1-AP2 box mutation exhibited a common ancestor

The hsp70.1-AP2 box mutation is inherited in a Mendelian manner as observed in the 9 half sib families analysed (not shown). An established pedigree involving all identified heterozygous and homozygous carriers (Figure 5) suggests a common ancestor of the carriers of the hsp70.1-AP2 box mutation in Holsteins. Tissue samples were not available for genotyping this sire. However, this mutation seems to be originated in Holsteins earlier because a son of this assumed ancestor exhibited a homozygous mutant $h s p 70.1$-AP2 box.

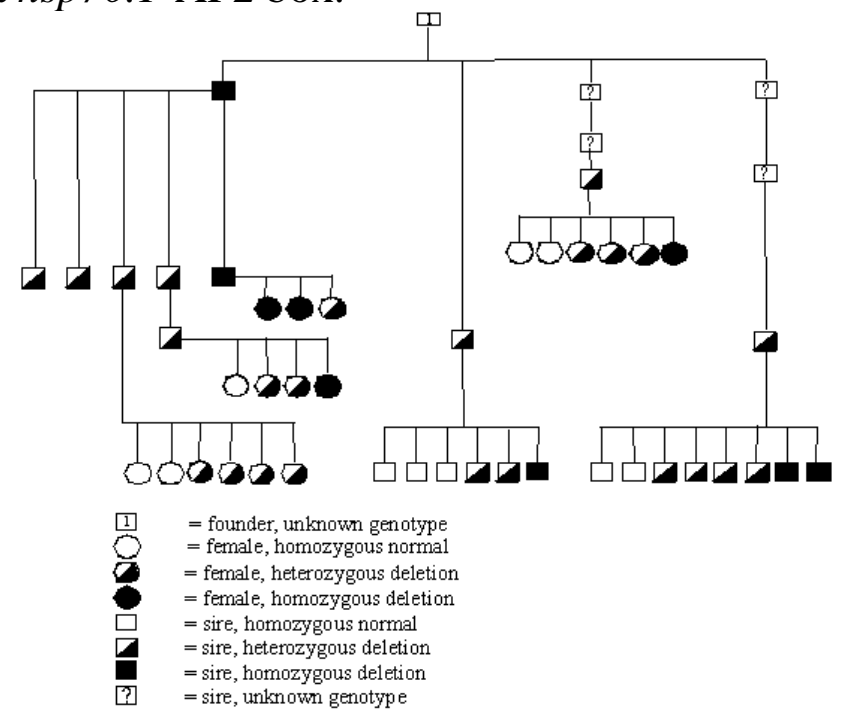

Fig. 5: Pedigree of the carrier of the -130-AP2 box mutation in the bovine hsp70.1 gene in Holstein cattle

\section{Discussion}

HSPs are critically important to cell survival (ELLIS, 1987; ELLIS and HEMMINGSEN, 1989; PECHAN, 1991; PELHAM, 1986; MORIMOTO and MILARSKI, 1990). In this regard, members of the HSP70 family have been shown to bind to cellular proteins during their synthesis, preventing premature folding and other protein-protein interactions (CRAIG and GROSS, 1991; HIGHTOWER, 1991). Promoter variants differing in potential cis-acting elements and showing impaired binding of corresponding transcription factors and significant negative effects on 
cellular stress response were described in the inducible bovine hsp70.1 gene and in its porcine homologue, respectively (SCHWERIN et al., 1999, 2001). Considering these HSP70 effects, a relationship of the functionally inactivated bovine $h s p 70.1$-AP2 box variant to stress susceptibility was assumed. In cattle, a suitable phenotypic trait characterising stress susceptibility is not available at present. Based on the assumption that animals having longer 'productive life' might be superior in coping with stress during lifetime the phenotypic trait 'productive life' could serve as an indicator for stress susceptibility. Therefore, in the present study the effect of the functionally inactivated bovine hsp70.1-AP2 box variant on the productive life was analysed. Our observations suggest that this polymorphism affects productive life in cattle. Animals with a normal AP2 box are characterised by an increased stress tolerance concluded from their prolonged productive life. These results are supported by the observed different distribution of the $h s p 70.1$-promoter variants in cows of different lactation number and stage of selection. Frequency of the mutant hsp70.1-AP2 box allele is significantly lower in cows selected as sire dams and in cows with a higher lactation number.

VAN LAAK et al. (1993) analysed the expression of hsp70 gene in porcine tissue using one- and two-dimensional PAGE and Western blotting and its potential relationship to stress susceptibility (assessed by meat quality and halothane sensitivity). Since there was a lack of correlation between Western blot signals and meat quality the authors concluded that there was no relationship between stress and the expression of the cognate and the inducible form of HSP70. However, because of the possible rapid degradation of HSP70 mRNA (MOSELEY et al., 1993) a reason for these results could be the time interval between the action of stress leading to poor meat quality and a presumable increased expression of heat shock proteins and the time of analysis. In additional studies RUOHONEN-LEHTO et al. (1993) and DEZEURE et al. (1993) found restriction fragment length polymorphisms, which could be useful in linkage studies, in the $h s p 70$ gene(s) in pigs of different breeds. The extent of the heat shock response was found to be different in various individuals in phenotypically different pigs. Because expression of inducible $h s p 70$ genes is regulated mainly at the transcriptional level (TANGUAY, 1988; WU et al., 1985), promoter variants of these genes may have special impact.

Summarizing present results in cattle, we assume that the observed increased hazard for culling cows with the functionally inactivated hsp70.1 promoter variant and the observed association of the mutant AP2 box with reduced productive life reflects the result of a reduced stress tolerance on extended and/or frequently affecting stress factors. Additionally, our observations suggest, that promoter variants do not behave neutral during selection. We conclude that selection of animals with an intact hsp70.1 promoter could contribute to an increase of stress tolerance in cattle. An increased stress tolerance should be associated with increased phenotypic performances because of improved expression of their genetic potential.

Acknowledgement

The authors wish to thank Annette Jugert and Joana Bittner for expert technical assistance. 


\section{References}

CAMERON, P. U.; TABARIAS, H. A.; PULENDRAN, B.; ROBINSON, W.; DAWKINS, R. L.:

Conservation of the central MHC genome: PFGE mapping and RFLP analysis of complement HSP70, and TNF genes in the goat. Immunogenetics 31 (1990), 253-264.

CRAIG, E. A.; GROSS, C. A.:

Is hsp70 the cellular thermometer? TIBS 16 (1991), 135-140

DEZEURE, F.; VAIMAN, M.; CHARDON, P.:

Characterization of a polymorphic heat shock protein 70 gene in swine outside the SLA major histocompatibility complex. Biochem et Biophys Acta 1174 (1993), 17

ELLIS, J. :

Proteins as molecular chaperones. Nature, London 328 (1987), 378-379

ELLIS, R. J.; HEMMINGSEN, S. M.:

Molecular chaperones: proteins essential for biogenesis of some macromolecular structures. Trends Biochem. Sci. 14 (1989), 339-342

GASKINS, H.R.; PROCHAZKA, M.; NADEAU, J. H.; HENSON, V. M.; LEITER, E. H.:

Localization of a mouse heat shock HSP70 gene within the $H$-2 complex. Immunogenetics 32 (1990), 286-289

GEORGES, M.; ANDERSSON, L.: Livestock genomics comes of age. Genome Research 6 (1996), 907-921

GROSZ, M. D.; WOMACK, J. E.; SKOW, L. E.:

Syntenic conservation of HSP70 genes in cattle and humans. Genomics 14 (1992), 863-868

GRUPE, S.; PANICKE, L.; DIETL, G.; KUEHN, CH.; GUIARD, V.; SCHWERIN, M.: Identification of loci with significant effects on stillbirth and calving difficulties in Holstein cattle. Arch. Anim. Breed., Dummerstorf 42 (1998), 151-158

HIGHTOWER, L. E.:

Heat shock, stress proteins, chaperones, and proteotoxicity. Cell 66 (1991), 191

MANIATIS, T.; FRITSCH, E. F.; SAMBROOK, J. (Eds.):

Molecular cloning. A Laboratory Manual. Cold Spring Harbor Laboratory, Cold Spring Harbor, NY (1982).

MOSELEY, P. L.; WALLEN, E. S.; MCCAFFERTY, J. D.; FLANAGAN, S.; KERN, J. A.:

Heat stress regulates the human $70-\mathrm{kDa}$ heat shock gene through the 3 '-untranslated region. Am. J. Physiol. 264 (1993), 533

MORIMOTO, R. I.; MILARSKI K. L.:

Expression and function of vertebrate hsp70 genes. In: R. I. MORIMOTO, A. TISSIERES, and C. GEORGOPOULUS (Eds.) Stress proteins in biology and medicine, pp 323-359, Cold Spring Harbor Laboratory Press, 1990.

NUNES, M.; YERLE, M.; DEZEURE, F.; GELLIN, J.; CHARDON, P.; VAIMAN, M.:

Isolation of four HSP70 genes in the pig and localization on chromosomes 7 and 14. Mammalian Genome 4 (1993), 247-251

PECHAN, P. M.:

Heat shock proteins and cell proliferation. FEBS Letters 280 (1991), 1-4

PELHAM, H. R. B.:

Speculations on the functions of the major heat shock and glucose regulated proteins. Cell 46 (1986), 959-961

RUOHONEN-LEHTO, M. K.; ROTHSCHILD, M. F.; LARSON, R. G.:

Restriction fragment length polymorphisms at the heat shock protein HSP70 gene(s) in pigs. Animal Genetics 24 (1993), 67

SARGENT, C. A.; DUNHAM, I.; TROWSDALE, J.; CAMPBELL, R. D.:

Human major histocompatibility complex contains genes for the major heat shock protein HSP70. Proc. Natl. Acad. Sci. USA 86 (1989), 1968-72

SAS Institute, SAS/STAT User's Guide, Version 8, Cary, NC: SAS Institute Inc. (1999)

SCHWERIN, M.; HAGENDORF, A.; FUERBASS, R.; TEUSCHER, F.:

The inducible stress protein70.2 gene - A candidate gene for stress susceptibility in swine. Arch. Anim. Breed., Dummerstorf 42 (1999), 61-66

SCHWERIN, M.; MAAK, S.; KALBE, C.; FUERBASS, R.:

Functional promoter variants of highly conserved inducible hsp70 genes significantly affect stress response. Biochem. et Biophys. Acta 1522 (2001), 108-111

TANGUAY, R. M.:

Transcriptional activation of heat-shock genes in eukaryotes. Biochem. Cell Biol. 66 (1988), 584

VAN LAACK, R. L. J. M.; FAUSTMAN, C.; SEBRANEK; J. G.: 
Pork quality and the expression of stress protein Hsp 70 in swine. J. Anim. Sci. 71 (1993), 2958

WU, B. J.; HUNT, C.; MORIMOTO; R. I.:

Structure and expression of the human gene encoding major heat shock protein HSP70. Mol. Cell Biol. 5 (1985), 330

WURST, W.; BENESCH, C.; DRABENT, B.; ROTHERMEL, E.; BENECKE, B.-J.; GÜNTHER, P.:

Localization of heat shock protein 70 genes inside the rat major histocompatibility complex close to class III genes. Immunogenetics 30 (1989), 46-49

Received: 2002-12-20

Accepted: 2003-02-25

Corresponding author's address

Prof. Dr. MANFRED SCHWERIN

Research unit of Molecular Biology

FBN Dummerstorf

Wilhelm-Stahl-Allee 2

D-18196 Dummerstorf

Germany 